\title{
SLOVENIAN COMPLEMENTARY HEALTH INSURANCE REFORM - DICHOTOMY BETWEEN THE INTERNAL MARKET AND THE SOCIAL DIMENSION
}

\author{
Bruno Nikolić ${ }^{1}$
}

\begin{abstract}
Complementary health insurance is divided between the internal market (market principles) and social dimension, wherein the state has an extremely difficult task, as it must create the conditions necessary for the fair and efficient functioning of the health care financing system. Slovenia has failed to successfully accomplish this task, which consists of both ensuring the social dimension and also facilitating the operation of market principles. The aim of this article is not on the functioning of market principles, which are covered by the field of economics, but is instead on analyzing the dichotomy between the internal market (the rules that govern the functioning of the internal market) and the social dimension (the rules that enable the exercise of the social function), and, in this light, analyzes the legal regulation of the Slovenian complementary health insurance. Analysis of the legal regulation highlights the shortcomings in ensuring the social dimension, shortcomings which are, with the help of the measures proposed in the concluding section of the article, remedied by the author.
\end{abstract}

\section{Keywords}

Complementary Health Insurance, Internal Market, Social Dimension, Earmarked Taxation

\section{Introduction}

Health insurance companies offering complementary health insurance have, unlike the compulsory health insurance institution (the Health Insurance Institute of Slovenia), mainly generated profit in recent years. These good results are not thanks to their successful business model, as would be expected for an activity of an economic nature, but are

${ }^{1}$ University of Ljubljana, Faculty of Administration, Gosarjeva ulica 5, SI-1000 Ljubljana, Slovenia. E-mail: Bruno.nikolic@fu.uni-lj.si. 
due to legal regulation of the health care financing system that almost "ensures" them successful business. The mere fact that the legal regulation creates favourable conditions for implementing economic or non-economic activity is undisputed. The establishing of a legal regulation that creates favourable conditions in which corporate entities can achieve successful business results is the main, and perhaps even the only, function of the state in the field of economics. However, it is a disputable fact that the state creates such conditions in the field, which is in the public interest, and that its fruits are mostly reaped by individuals and not the society as a whole, as would be expected for such activity. By deciding to leave the implementation of such an important activity that is an integral part of social security - namely, the financing of health care - to the corporate entities that carry out this activity in an entrepreneurial spirit, the state does not fail to live up to its positive obligations under the principle of the welfare state, but must still provide for this activity to be carried out in compliance with its social function. Even though complementary health insurance represents an essential and indispensable part of the social security system, the current legislative regulation falls far short of sufficiently pursuing the social function, a condition which is emphasized by recent legislative changes. ${ }^{2}$

Strong state regulation is a necessary prerequisite for organizing and implementing the activity of complementary health insurance covering statutory cost sharing, since the insurance is inextricably linked to the compulsory health insurance by which it significantly contributes to ensuring social security. The regulation of complementary health insurance pursues two basic objectives: (i) in the light of protecting the public interest, it ensures the implementation of the social function, and (ii) it facilitates or enhances the operation of market principles, which increases the economic efficiency. Complementary health insurance is thus divided between the market, or market principles, and the social dimension, wherein the state has an extremely difficult task, as it must create the conditions necessary for the fair and efficient functioning of the health care financing system. The real status of the Slovenian complementary health insurance significantly deviates from the described theoretical framework. State regulation still falls far short of achieving its objectives both in terms of protecting the public interest (achieving the social function and principles of solidarity) and in facilitating the operation of market principles ${ }^{3}$. The aim of this article is to analyze the dichotomy between the internal market (the rules governing the functioning of the internal market - economic freedoms and competition law) and the social dimension (the rules ensuring that the social function is achieved), and to analyze in this light the legal regulation of the Slovenian complementary health insurance. This will reveal the shortcomings in the legal regulation of complementary health insurance and possible solutions to overcome them, the discovery of which is the main purpose of this article.

\footnotetext{
${ }^{2}$ Public Finance Balance Act (Official Gazette of RS, No. 40/12 of 30. 5. 2012) and the Law on Health Care and Health Insurance Act-M (Official Gazette of RS, No. 91/2013 of 5. 11. 2013).

3 This view is also shared by Tajnikar, Došenovič Bonča, etc. (2015).
} 


\section{Dichotomy between the internal market and the social dimension in EU law}

The aim of the EU internal market is to increase competitiveness, specialization and economy of scale through which the economic efficiency of the entire zone is increased. The increase in economic efficiency by itself does not represent the ultimate goal of the internal market, but merely the means by which social welfare is maximized. ${ }^{4}$ By analogy, such reasoning can also be applied to economic growth, which does not constitute a social goal in itself, but merely the means of maintaining or improving the population's standard of living. The economy has to be understood in this context as leverage by which higher social goals are pursued, namely to improve social welfare and the population's standard of living. The economic efficiency and economic growth per se do not improve social welfare and the standard of living, but are merely a necessary condition to achieve these goals. ${ }^{5}$

The internal market falls within the shared competences of the EU and its Member States (Article 4 (2) of the TFEU), while the EU has exclusive competence in the field of competition law (Article 3 (1) of the TFEU). Through exclusive legislative competence in the field of competition law, which is a means to achieve the internal market ${ }^{6}$, the EU pursues economic efficiency, namely its ultimate goal - the maximization of social welfare. ${ }^{7}$ Social services also constitute an integral part of social welfare, in particular, access for the population to services that, in the light of the European legal language, may be understood as social services of general interest. In this regard, a classic dichotomy between the market, namely the competition law and economic freedoms, which govern the functioning of internal market, on the one hand, and the social dimension as its antipode, is surpassed. Inductive reasoning leads us to the conclusion that the goal of competition law and economic freedoms is to maximize social welfare, which also implies access to social services of general interest. If we justify the reduction of social dimension or access to services of general interest by increasing economic efficiency, we concurrently move away from the ultimate goal of the internal market, since we diminish social welfare.

The European Community and the European Union have emphasized throughout their entire development the role and importance of the internal market and competition law, and this has been reflected in the development of the social dimension. ${ }^{8}$ This can be seen in the field of health care financing, especially in the development of social services of general interest, the persistent decrease in the classification of non-economic activities and restrictive interpretation of the EU acquis in assessing the compliance of national regulatory measures that affect market principles and restrict economic freedoms. Such an

\footnotetext{
${ }^{4}$ This view is shared by Sanchez A. Graells (2011).

${ }^{5}$ Other socio-economic factors (e.g. access to services of general interest) also have an impact on maximizing social welfare and improving the standard of living.

6 This view is shared by Lianos (2013).

${ }^{7}$ A consequentialist or utilitarian approach also prevails with regard to the objectives of EU competition law under the Lisbon Treaty, which is based on increasing social welfare. See Lianos (2013).

${ }^{8}$ Such an approach is, in the light of the economic nature of European integration as its main guideline, completely understandable.
} 
approach, as directed by the "guardian" of European interests, the European Commission, often requires that Member States abolish national regulatory measures even in those fields which are identified as public interest by those states. Activities pursuing a social function, social services of general interest in particular, are especially vulnerable to this kind of intervention, especially in cases where such measures affect the population's social security.

The beginnings of a new approach that goes beyond the binary rhetoric and the primary role of the internal market have been seen increasingly frequently in the last decade in both the political and legal sphere of the EU. The debt crisis that ravaged through the whole of Europe and the subsequent recession, which some countries are still facing today, have had a strong impact on the social dimension of European countries. The growing importance of the social dimension, which is, in times of crisis, put under additional pressure, has been also increasingly acknowledged by European institutions. ${ }^{9}{ }^{10}$ In this light, the Lisbon Treaty has created a new concept of a social market economy, which creates a marketoriented economy with a social dimension (Semmelmann, 2010; de Vries, 2011). The purpose of this new concept, which is closer to the interpretative principle rather than to the goal of competition law, is to transform the EU towards greater acknowledgment of different aspects of the population's welfare. ${ }^{11}$ The case law of BUPA also presents a strong shift in this direction, which reflects the socially-oriented intervention of the General Court in the field of competition law. In assessing state aid in the financing of a service of general economic interest (Irish complementary health insurance), the Court established a new approach called, by De Vries, the jurisdictional approach to the assessment of state aid. This newly-created approach departs from the often criticized and almost obsolete economically-oriented approach that takes into account economic factors to a much greater extent (the $3 \mathrm{rd}$ and the 4 th conditions of the Altmark judgement ${ }^{12}$ ). The Court has brought the assessment of the characterization of a service of general economic interest and the entity providing that service to the forefront, thereby consolidating the discretion of the Member States in the regulating and financing of a service of general economic interest. ${ }^{13}, 14$

Recent reforms of EU primary law and the jurisprudence of the Court clearly indicate that these institutions are progressively acknowledging the social dimension by which the internal market and competition law are not perceived solely in the light of the neoliberal

\footnotetext{
${ }^{9}$ See the judgement of the Court of Justice of the European Union in Case C-341/05, Laval [2007]; the European Parliament resolution of 20 May, 2010, on delivering a single market to consumers and citizens (2010/2011(INI)); the Communication from the Commission to the European Parliament, the Council, the European Economic and the Social Committee and the Committee of the Regions: the Single Market Act - Twelve levers to boost growth and strengthen confidence - "Working together to create new growth", $\operatorname{COM(2011)~206/4,~} 13$ April, 2011.

${ }^{10}$ Seen through the prism of historical development of the European Community and the EU, the Member States protect and pursue the social dimension to a much greater extent.

${ }^{11}$ Lianos (2013).

${ }^{12} \mathrm{C}-280 / 00$, Altmark Trans GmbH in Regierungspräsidium Magdeburg v. Nahverkehrsgesellschaft Altmark $\mathrm{GmbH}$ [2003].

${ }^{13}$ Slovenian complementary health insurance is also classified as a service of general economic interest (Nikolić, 2015a).

${ }^{14}$ De Vries (2011).
} 
or ordoliberal project, but also in the light of social welfare. ${ }^{15}$ Perhaps such a stance paves the way for a new paradigm which does not distinguish so strictly between the internal market and the social dimension, and finally acknowledges that the ultimate goal of both is the same - to maximize social welfare. Such an approach requires that, in assessing the socially- and solidarity-oriented national regulatory measures in the field of services of general economic interest, it must be taken into account that, by decreasing the social dimension of these services, social welfare is also being diminished, which is contrary to the ultimate goal of the internal market and competition law.

\section{Complementary health insurance between the internal market and the social dimension}

In Slovenia, recent legislative changes in the field of health care financing show just the opposite trend. Not only did Slovenia not take advantage of the changing trend, namely the new paradigm, and more successfully defend the socially-minded national regulatory measures which the European Commission had claimed infringed the rules governing the functioning of the internal market, but it abolished the measures in whole and thereby further reduced the social dimension of the complementary health insurance. The current legislative regulation of the complementary health insurance far from pursues the objective of protecting public interest (social function) to the extent as would be expected for an activity that is an element of basic social security.

The Slovenian health care financing system is based on two sources of financing: compulsory health insurance provided by the Health Insurance Institute and complementary health insurance provided by the health insurance companies. Compulsory health insurance is a central pillar of financing, and in 2014, appropriations under this title constituted $62.9 \%$ of total health care expenditure (5.73\% of GDP) (Health Insurance Institute of Slovenia, 2015). ${ }^{16}$ Complementary health insurance is the second-largest source of financing, and in 2014, appropriations under this title constituted between 400 and 450 million euro, which represents around $14 \%$ of all health care expenditure. ${ }^{17}, 18,19$ Compulsory and complementary health insurance are inextricably linked, since they guarantee the same benefits. Compulsory health insurance does not cover all health care services, but only those set by the statutes. ${ }^{20}$ The full cost of health care is covered for only a handful of services provided

\footnotetext{
15 This view is also shared by de Vries (2011) and Lianos (2013).

16 The remaining public funds represented the municipal budget funds and the state budget funds, including investments by the state and municipalities (6.3\% of total resources) and funds for long-term health care expenditure (Pension and Disability Insurance Institute Supplement: 2.3\% of total resources) (Health Insurance Institute of Slovenia, 2015).

17 Gracar (2014).

18 The remaining private funds represented the individuals' direct payments $(12.7 \%$ of total resources) and resources from companies and non-profit operators (1.6\% of total resources) (Health Insurance Institute of Slovenia, 2015).

${ }^{19}$ In the EU, a comparable share of voluntary health insurance can be found in France (14\%), Ireland (12\%) and Germany (10\%). Within OECD member countries, the share of voluntary health insurance exceeds Slovenia only in the US (35\%) and Chile (17\%) (see OECD, 2013).

${ }^{20}$ Article 23 of the Health Care and Health Insurance Act.
} 
for in a special national program, and for all other services, an insured person must pay the difference between the statutory covered price and the full price of the service (copayment) directly to the medical service provider. The proportion of co-payment depends on the category to which a particular health service is assigned. The health services that have the greatest social importance and the services that represent the largest financial burden for an individual are covered by compulsory health insurance in full or to a larger proportion. ${ }^{21}$ Users may make a co-payment directly to the medical service provider or take out (voluntary) complementary health insurance for this purpose. ${ }^{22}$ The nature of complementary health insurance, which is strongly imbued with social connotations, and the important role of the social security system resulted in a definition of insurance which represents the public interest of the Republic of Slovenia. Suitably strong regulation of insurance ranks, within this meaning, foremost among the voluntary health insurances in the EU.

\section{Complementary health insurance as an activity of the public interest}

The legal regulation of complementary health insurance was already, before the abolition of the regulatory measures analyzed below, suited to the complementary health insurance providers, since it created a friendly environment and conditions that almost guaranteed them successful business. ${ }^{23}$ This is largely a result of the systemic regulation of health care financing, which offers under the compulsory health insurance such a limited range of benefits that residents in search of social security are forced to resort to complementary health insurance. ${ }^{24}$ The best evidence for that is coverage with complementary health insurance, which is almost universal. ${ }^{25}$ In this light, Slovenia has defined complementary health insurance as a public interest, since the insurance does not only offer additional social security depending on the individual's preferences and risk-taking, but is an integral and essential part of the basic (compulsory) system of social security. Complementary health insurance is perceived by most of the population as disguised "compulsory" insurance and equally a single insurance premium for complementary health insurance as a disguised "compulsory social security contribution". Social contributions are usually characterized by a high degree of solidarity and a certain degree of equity subsidization ${ }^{26}$ which does not apply to the complementary health insurance premiums. The insurance premiums are the

\footnotetext{
${ }^{21}$ Transplants, intensive care treatment, dialysis, systematic medical examination for children and pregnant women, emergency medical aid, etc.

${ }^{22}$ Complementary health insurance for users' co-payments.

${ }^{23}$ Rough estimate of the cumulative profits of health insurance companies offering complementary health insurance accounted in a period from 1. 3. 2006 until 31. 12. 2013: around 70 million euro (Nikolić, 2015c).

${ }^{24}$ Co-payments for health services under the compulsory health insurance vary between $10 \%$ and $90 \%$ of the price of medical services. Due to the high price of health services and low percentage of coverage under the compulsory health insurance, some co-payments may be classified into the category of "catastrophic" health expenses, since they exceed 20,000 euro (see Mikeln, 2014).

${ }^{25}$ In 2012, complementary health insurance had concluded on average 1,431,951 insurance policies (see Gracar, 2014). As a comparison, we present the figure that 2,076,273 insured persons were included by the end of 2012 in the compulsory health insurance, of whom 1,536,876 were policyholders and 539,397 were family members (Health Insurance Institute of Slovenia, 2013).

${ }^{26}$ See Schieber in Gottret (2006).
} 
same for all insured persons, which increases the regressivity of the health care financing system. ${ }^{27}$ Disregarding direct payments, complementary health insurance represents the most regressive part of the health care financing system, as the amount of the premium, after the Public Finance Balance Act entered into force, is entirely within the discretion of the complementary health insurance providers and has no relation to the individual's income. In this light, there is a significant disparity between the contribution for compulsory health insurance and the complementary health insurance premium. Compulsory health insurance premiums are assessed based on a percentage value of the individual's gross income, which is more equitable compared to the complementary health insurance premium. Contrary to the nature of complementary health insurance, which is considered by the majority of the population as "compulsory" 28 , the insurance premiums are far from pursuing social function and solidarity principles to such an extent as is typical of compulsory insurances. It is extremely difficult to conclude that, in accordance with the definition of complementary health insurance, such regulation of the insurance premium is in the public interest.

Complementary health insurance providers (providers of a service of general economic interest), despite the favorable legal regulation, do not give back to society any more than any other corporate entities which carry out "normal" economic activities - on the contrary. With the elimination of the provision which prescribes them to devote half the profit from complementary health insurance to implement this activity, as discussed below, complementary health insurance providers are subject to better treatment than most other insurance business providers. Health insurance companies conducting complementary health insurance do not, unlike most other insurance business providers, pay tax on insurance transactions. ${ }^{29}$ Accordingly, the health insurance companies have a minimal social role in terms of a strong social function, as they "give back to society" less than health insurance companies from most other insurance policies having a markedly weaker social function. This is disputable in several respects, firstly, in terms of the social importance of complementary health insurance; secondly, the social function that the providers of such insurance hold; and thirdly, in terms of equity and fairness both to the population and to the other entities engaged in insurance business carried out in not so "favourably" regulated environments. Therefore, it is surely more appropriate that the health insurance companies carrying out such a distinct socially-oriented activity should also behave accordingly and pursue social function to a greater extent.

\footnotetext{
${ }^{27}$ For more regarding the regressivity of the Slovenian financing system, see the WHO report, which ranks Slovenia at $82 \mathrm{nd}$ place with respect to the fairness of the financial contribution to health care. The survey presents only a framework indicator as it is outdated, and it has also received a certain amount of professional criticism, further reducing its credibility. See WHO (2000) and Wagstaff (2001).

${ }^{28}$ Complementary health insurance is a voluntery insurance scheme which operates according to insurance principles.

${ }^{29}$ For more on the exemption of the health insurance companies from paying tax on insurance transactions, see Nikolić (2015d).
} 


\section{Abolishment of the social measures in the legal regulation of complementary health insurance}

By entering into force the Public Finance Balance Act, which abolished the approval of an increase in complementary health insurance premiums during its term (Point 6 of the second paragraph of the Article 62 of the Health Care and Health Insurance Act) and the Law on Health Care and Health Insurance Act-M, which abolished the obligation of complementary health insurance providers to return half of the profit from complementary health insurance to implement this activity (Point 4 of the second paragraph of the Article 62 of the Health Care and Health Insurance Act), the legal regulation of complementary health insurance has become even more friendly to its providers, and the pursuit of social function decreased even further. ${ }^{30}$ Slovenian legislators have, in the name of increasing the economic efficiency of complementary health insurance providers, eliminated those provisions which represented social correctives in the financing of this activity. This raises the question of whether social welfare has decreased on this account.

Both of the abolished provisions were social measures which were designed to ensure or improve access to complementary health insurance. By abolishing the provision on the basis of which complementary health insurance providers were obliged to return half of the profit from complementary health insurance business to implement this activity, the legislator has reduced access to complementary health insurance or social welfare only in theory. The health insurance companies have only accumulated their half of the profit from complementary health insurance in a special balance sheet item by which they did not contribute to achieving any objectives in the public interest nor pursue any social function - ensuring and improving access to complementary health insurance. The consequence of an inadequate legal regulation, which did not actively direct the means resulting from a positive balance of complementary health insurance to pursue the social function, was an infringement of the free movement of capital within the meaning of Article 63 TFEU. ${ }^{31}$ In other words, the legislator has abolished the provision that represented a social corrective, in the name of increasing economic efficiency, by which social welfare was not diminished, since the provision abolished did not contribute in any way to maintaining or improving access to complementary health insurance.

In abolishing the provision of the Health Care and Health Insurance Act, which specified prior approval of the increase in premium rates for complementary health insurance during the insurance term, a dichotomy can also be observed between the rules governing the functioning of the internal market and the provision of national law, which constitutes a social corrective in the financing of the complementary health insurance. The Court has ruled in Case C-185/11, the Commission v Slovenia [2012], that the national provision in question had infringed Article 8(3) of the First and Articles 29 and 39 of the Third Non-life Insurance Directive ${ }^{32}$, which prohibit the maintenance or introduction of prior

\footnotetext{
${ }^{30}$ For more on the elimination of both provisions of the Health Care and Health Insurance Act, see Nikolić (2015b).

${ }^{31}$ For more on non-conformity of the relevant provision with the EU acquis, see Nikolić (2015b).

${ }^{32}$ The First Non-life Insurance Directive 73/239/EEC (Official Gazette L 228, 16/08/1973, P. 0003-0019) and the Third Non-life Insurance Directive 92/49/EEC (Official Gazette L 228, 11/08/1992, P. 0001-0023).
} 
notification or approval of proposed increases in premium rates. ${ }^{33}$ The Slovenian legislator has abolished the disputed provision, and therefore the amount of the insurance premium was put fully within the discretion of the complementary health insurance providers. The social corrective set out to restrict the health insurance companies from arbitrarily or unjustifiably increasing in insurance premiums, by which access to complementary health insurance would be reduced, was submitted to the EU acquis governing the functioning of the internal market (free determination of premium rates). ${ }^{34}$

The non-conformity of the national provisions with the EU acquis is in no way called into question, but the way in which the legislator eliminated this non-conformity, as a result of the dichotomy between the internal market and the social dimension, can be disputed. Despite the fundamental principle of prohibiting any restriction on the free movement of capital and the freedom to set premium rates, the Member States can restrict both principles to some extent through national measures pursuing the social dimension, provided that they are in accordance with the exceptions in the EU acquis (e.g. the restriction on the free movement of capital can be justified by the overriding reasons in the public interest ${ }^{35}$, and the restriction on freedom to set premium rates in the context of a general price-control system $^{36}$ ). Slovenia has not taken up this possibility in proceedings before the Court nor later when amending the contested legislative provisions. Instead of a well-considered legislative change that would harmonize the legitimate purpose of both provisions disputed (social corrective for financing of complementary health insurance) with the rules on the functioning of the internal market, the legislator has completely abolished both provisions, and thereby completely divided the social dimension and the internal market, which is contrary to our starting premise.

\section{Complementary health insurance reform - a shift to a social dimension}

In the concluding part of the article, we will try to overcome the dichotomy between the internal market and the social dimension, and in this light, propose a reform of the Slovenian complementary health insurance. The aim of the reform is to enhance the social dimension in the legal regulation of complementary health insurance, which will be in accordance with the EU rules on the functioning of the internal market.

\footnotetext{
${ }^{33}$ For more on the non-conformity of the relevant provision with the EU acquis, see Nikolić (2015b).

${ }^{34}$ This provision also has not contributed to achieving objectives in the public interest - ensuring and improving access to complementary health insurance. This can be proved by the fact that by increasing the premium rate in 2012, the health insurance companies have recorded almost 30 million euro higher income from premiums during the period from January to September 2013, even though the insurance claims within the same period increased only by 17 million euro (see Ivanjko, 2013). This is an excellent indicator of an arbitrary and unjustified increase in insurance premiums, which is contrary to the purpose of the provision.

${ }^{35}$ For more on overrriding reasons in the public interest, see Campus Oil Limited and others [72/83, sections 34 and 35], Commission of the European Communities v Kingdom of Belgium [C-503/99, section 46], Commission of the European Communities v Italian Republic [C-260/04, section 40] in Staat der Nederlanden v Essent NV and others [C-105/12 to C-107/12, section 59].

${ }^{36}$ For more on general price control system, see DKV Belgium v Association belge des consommateurs TestAchats ASBL [C-577/11].
} 
As an alternative measure to the (i) abolished provision that imposes upon the health insurance companies a requirement to return half of the profit from complementary health insurance to implement this activity (ii) regressive complementary health insurance premium and (iii) inadequate regulation on the turnover taxation from insurance business, we suggest the earmarked taxation of the complementary health insurance contracts. The health insurance companies would be charged, in addition to the existing corporate income tax, earmarked tax on complementary health insurance premiums which would be transferred into a special earmarked fund. The sole purpose of such taxation is to establish a social corrective which would increase the social dimension of the service of general economic interest. With regard to the profit of around 70 million euro created by the health insurance companies based on the complementary health insurance in the period from early 2006 until the end of 2013, the argument concerning an excessive tax burden on health insurance companies can be rejected. The funds transferred into the earmarked fund on the account of a new taxation would be used to increase access to complementary health insurance in a manner of (a) subsidizing the complementary health insurance premiums for individuals who are in a disadvantaged social position, but are not entitled to a complementary health insurance coverage on another basis (e.g. Article 24 or 25 of the Health Care and Health Insurance Act) or (b) it could be used to lower the insurance premium, thereby also improving access to complementary health insurance. In this way, not only would access to complementary health insurance increase, and thereof the implementation of the social dimension of the insurance would improve, but also the regressivity of insurance premium would diminish, thus improving the implementation of the solidarity principles.

Strong regulation of complementary health insurance does not offer many options to the health insurance companies to use different business strategies to compensate for the fall in profits which would result from earmarked taxation. It is most likely that they would increase the premium rates of complementary health insurance, a move which is, upon the abolishment of the provision of the Health Care and Health Insurance Act on prior approval for the increase in premium rates for complementary health insurance, completely at their discretion. In this way, they would try to reverse the burden of reduced profits to policyholders. Current legal regulation does not contain a provision that would prevent the health insurance companies from applying this strategy. Nevertheless, a general pricecontrol system in terms of a technical framework, governing how insurance undertakings are to calculate their premiums, is not contrary to the legal rules governing the functioning of the internal market. ${ }^{37}$ With the objective of preventing arbitrary increases in insurance premiums by which the health insurance companies could compensate for the loss in profits as a result of a earmarked taxation, a general price-control system for calculating the insurance premium based on a clear framework and transparent criteria would be introduced. A technical framework that would allow the health insurance companies to increase the insurance premium would be based on the health index demonstrating the

37 The Court has confirmed in Case C-577/11, DKV Belgium SA v Association belge des consommateurs Test-Achats ASBL[2013] that the technical framework, which is part of general price-control system, does not infringe EU acquis. 
costs of the services covered by complementary health insurance. The health insurance companies could justify the increase in the premiums only by an increase of the equivalent health index or by obtaining a special authorisation from the administrative authority in exceptional cases, where a non-increase in the insurance premiums would undermine their business. Consequently, the health insurance companies would be prevented from reversing the costs of the earmarked tax on its policyholders, which would ensure the purpose of the earmarked taxation.

\section{Conclusion}

The proposed reform of the complementary health insurance is based on the given theoretical starting points that go beyond the dichotomy between the internal market and the social dimension and are in line with the goal of maximizing social welfare. In regulating the services of general economic interest, especially when they play an important role within the social security system, the legislator must, in addition to ensuring the operation of the market principles which promote economic efficiency through the rules on the functioning of the internal market, also ensure the social dimension of these services. Current legal regulation of complementary health insurance is still far from providing the social dimension to such an extent as would be expected for an activity that is part of basic social security. The earmarked taxation of the complementary health insurance contracts presents a measure to overcome this shortcoming. In addition to increasing the social dimension of complementary health insurance, which is reflected in improved access to complementary health insurance, such a measure would also diminish the regressivity of insurance premiums, thus improving the solidarity principles in the insurance.

\section{References}

De Vries, S. A. (2011). BUPA; Healthy Case, in the Light of a Changing Constitutional Setting in Europe?, in de Gronden, J. W., Neergaard, U., Szyszczak, E. and Krajewski, M. (eds.). Health Care and EU Law, Legal Issues of Services of General Interest. The Hague: T.M.C. Asser Press.

Gracar, I. (2014). Spremembe financiranja sistema zdravstvenega varstva RS (Working Paper). Ljubljana.

Graells, S. A. (2011). Public Procurement and the EU Competition Rules. Oxford: Hart Publishing.

Health Insurance Institute of Slovenia. (2013). 2012 Management Report. Ljubljana: Health Insurance Institute of Slovenia.

Health Insurance Institute of Slovenia. (2015). 2014 Management Report. Ljubljana: Health Insurance Institute of Slovenia.

Ivanjko, Š. (2013). Zavarovalnice v krizi dobro poslujejo, ker strah zaradi negotovosti povečuje potrebo po zavarovanju. Večer.

Lianos, I. (2013). Some Reflections on the Question of the Goals of EU Competition Law (CLES Working Paper Series 3/2013). London: Centre for Law, Economics and Society CLES, Faculty of Laws, UCL. 
Mikeln, A. (2014). Pomen zasebnih sredstev za dolgoročno stabilnost zdravstvenega sistema, na posvetu Zdravstvena polemika: Kakšna bo cena vašega zdravja v prihodnje. Ljubljana.

Nikolić, B. (2015a). Definition of Slovenian Complementary Health Insurance as a Service of General Economic Interest. International Public Administration Review, 13(1): $29-47$. Nikolić, B. (2015b). Impact of the Balancing Public Finances Act and the Law on Health Care and Health Insurance Act-M to Finance Complementary Health Insurance (Working Paper). Ljubljana.

Nikolić, B. (2015c). Legal Regulation of Health Care Financing Systems (Doctoral dissertation). Ljubljana: Faculty of Law.

Nikolić, B. (2015d). Why the Complementary Health Insurance Providers Are Exempted from Paying the Tax on Insurance Premium Transactions. Pravna praksa, 34(35):14-16. Organisatation for Economic Co-operation and Development (OECD). (2013). Health at a Glance 2013: OECD Indicators. Paris: OECD Publishing.

Schieber, G. and Gottret, P. (2006). Health financing revisited, a practicioner's guide. Washington: The World Bank.

Semmelmann, C. (2010). The European Union's Economic Constitution under the Lisbon Treaty: Soul-Searching Shifts the Focus to Procedure. European Law Review, 35(4), 516-542.

Tajnikar, M., Došenovič Bonča, P. et al. (2015). Projekt prenove gospodarskih vidikov slovenskega zdravstva. Retrieved 14.7.2015 from University of Ljubljana, Faculty of Economics Web site: http://efnet.si/wp-content/uploads/Projekt-prenove-gospodarskih-vidikovslovenskega-zdravstva_sklepi1.pdf.

Wagstaff, A. (2001). Measuring Equity in Health Care Financing: Reflections on and Alternatives to the World Health Organization's Fairness of Financing Index (Policy Research Working Paper). Washington: World Bank.

World Health Organization (WHO). (2000). The World Health Report 2000. Health Systems: Improving Performance. Geneva: WHO. 